\title{
ASYMMETRY OF ECOWAS INTEGRATION PROCESS: CONTRIBUTION OF REGIONAL HEGEMON AND SMALL COUNTRY
}

\author{
Omo-Ogbebor O. Dennis, Hajj Ahmed Sanusi \\ Peoples' Friendship University of Russia (RUDN University), Moscow, Russia
}

\begin{abstract}
This article deals with the role of Nigeria and Ghana in ECOWAS specific fields of integration since its creation in 1975. It showed the relevance of Nigeria as a regional leader and the importance of Ghana as a key factor in ECOWAS integration process, and their respective foreign policy stand towards West African integration process in the present century.

In order to evaluate and present the role of Nigeria and Ghana in ECOWAS integration process, the authors set out three main tasks to actualize it. The first task is to identify the main areas of ECOWAS integration process, namely: economic integration, security formation and political reformation using qualitative methodological analysis to achieve this task. The second task is the review of ECOWAS operational structure, which explained how Nigeria was able to exert its hegemony status in ECOWAS, and how Ghana is able to remain useful in ECOWAS despite the overwhelming influence of Nigeria. The third task is using historical analytical method to present facts and explain the various contributions by Nigeria and Ghana in ECOWAS economic liberation process, peacekeeping operations, and political interventions in ECOWAS member states which have brought relative peace and security to the region.

The authors draw conclusion based on the result of the research analysis that, in spite of ECOWAS compositions which include the Francophone countries in the region and its leadership structure, Nigeria and Ghana have led by example, by devoting much attention and commitment to the ECOWAS integration process through mediations, peacekeeping, political intervention and economic cooperation.
\end{abstract}

Key words: Nigeria, Ghana, integration, ECOWAS, ECOMOG, Africa, foreign policy, economic, peacekeeping, political reforms

Various sub-regional organizations in Africa and individual states have assumed increasing security, political reformation and economic liberation policies. Unlike the early days of independence, where ruling elites were less willing to hand over power to others and democracy was rarely identified, various states in recent decades have exercised democratic governance in various ways. Series of coups, ethnic, geographical, and religious conflicts ravaged significant sections of the continent. This posture painted a picture of a continent trapped in perpetual crisis. Political ideology of most West African leaders today is to integrate the region with ideals of Pan-Africanism and to sustain one territorial jurisdiction through the regional organization ECOWAS. S. Radelet contends that, "There surely has been much failure, conflict, and stagnation. Deep challenges continue. But the image of an entire continent mired in failure and hopelessness is increasingly out of date" [Radelet 2010]. The treaty of Lagos aimed at socio-economic and other developmental activities of the region, since the success of integration is essential for Africa. F. Herrera argues that, "economic integration is a response to political challenge, a political response that is also a political process" [Herrera 1963].

Although the initial purpose of ECOWAS was to promote economic integration for it members, the organization expanded its mission to deploy military forces into Li- 
beria, Sierra Leone, and Guinea Bissau in 1990, 1997, and 1998, respectively, and then to Cote d'Ivoire and Liberia in 2003, and recent political interventions which is always precursor to conflicts in the region. These interventions opened up new avenues for the maintenance of international peace and security.

Nigeria as a hegemon in ECOWAS has played the role of regional stabilizer based on its leadership ability in enforcing ECOWAS programs and policies while Ghana remains a shining light in ECOWAS due to its steady democratic process which started from 1992 election, guided by a new Constitution (the 1992 Constitution), the 1996 peaceful election, the peaceful transition of powers from one party to another in 2001, 2009 and 2017 attest to improve aspect of regional integration process.

\section{ECOWAS BETWEEN ANGLOPHONES AND FRANCOPHONES}

The Economic Community of West African States has undergone various transformations to meet contemporary challenges since the signing of the treaty of establishment in 1975 by member states more than four decades ago in Lagos. The major changes in ECOWAS during this period of existence is the ECOWAS Revised Treaty signed in Cotonou in July 1993, while the Treaty of Cotonou is divided into 22 chapters and 93 articles, each chapter dealing with specific issues. ECOWAS Institutions are saddle with the responsibilities of running the organization and decision making, and it is loosely patterned after the European Union. The Institutions includes; the Authority of Heads of State and Government; the Executive Secretariat; the Council of Ministers, the Fund for Cooperation Compensation and Development; ECOWAS Parliament; an Economic and Social Council; the Court of Justice and the Specialized Technical Commissions. Each institution is tasked with certain duties and delegated a specified degree of power in order to effectively carried out it programs, policies and objectives to the length and breadth of the region ${ }^{1}$.

Authority of Heads of State and Government is the supreme institution and the highest decision making body in ECOWAS and is composed of Heads of State and or Government of Member States. The Authority is responsible for the general direction and control of the Community and takes all measures to ensure its progressive development and the realization of its objectives. The office of the Chairman is held every year by a Member State elected by the Authority. The voting procedure is one member, one vote to give the smaller countries in the organization sense of belonging, and to respect their sovereign right as a nation thereby eliminating the fear of domination by bigger nations in the organization.

Despite this arrangement, there was still division along colonial ties among ECOWAS member states, leading to two major blocs within the organization which are the Anglophone bloc made of up English speaking countries colonized by Great Britain, and the Francophone bloc comprises of French speaking countries colonized by France. Nigeria has been able to douse the presumption of fear of domination always express by its West Africa neighbors concerning the "big brother"" tag. Though, "Nigeria

1 ECOWAS Revised Treaty 1993. URL: http:/www.ecowas.int/wp-content/uploads/2015/01/ Revised-treaty.pdf (accessed: 13.03.2016). 
overshadows every other country in the region in terms of population, gross domestic product, and natural resource endowment. An effort has been made to counterbalance this by placing ECOWAS member states on an equal footing in all things except in the area of financial contributions to the Community which is another big achievement for Nigeria, bearing the burden when it comes to carrying out political assignment in the region" [Nwoke 2005: 111]. And Nigeria handling of French political influence in the region without open confrontation which tend to provoke and sustain this fear of domination, as they strive to maintain their sphere of influence commendable, making the interests of the Community a top priority, that issues be carefully dealt with to dispel any remaining fears and promote greater commitment to the regional integration process.

Nigeria and Ghana are dependable allies even before the formation of ECOWAS. Right from the days of colonial struggle, both countries were colonized by Great Britain, and surrounded by their Francophone neighbors, have always being on the same side when it comes to major decision making in ECOWAS. Hence the threat posed by Francophone countries in ECOWAS is minimized as in the case of Liberian crisis and Sierra Leone. Although, ECOWAS member has equal voting power at the highest level of decision making but Nigeria has a way of using diplomatic maneuvering among smaller member states in ECOWAS to exercise its hegemonic status in the region because of its overwhelming contributions to the organization. This is why many view all regional organizations regardless of their purpose, be it economic well-being or monetary cooperation as political in nature. Not only do political objectives motivate the establishment of these organizations; political actions also bring them into being and it is politics that characterizes their functioning too. As entities, these organizations are marked by conflict among participant actors, over goals and over the distribution of costs and benefits just as is politics at the national level. As buttressed by J. Cochrane that; "It is not going too far then to say that regional organizations are in reality political systems" [Cochrane 1969: 7].

It is only in ECOWAS institution of Parliament, Nigeria has superior votes to other member states because of its population size but the ECOWAS Parliament plays an essentially consultative role which is not binding on the authority of heads of state and government: it provides advisory opinion on issues covering a wide range of areas that are of crucial importance for the integration process. These include respect for human rights, the interconnection of communication and telecommunication links, health, education, and revisions of basic community texts. The ECOWAS Parliament has 115 seats, which are distributed among the 15 ECOWAS Member States on the basis of their population. Nigeria, which has by far the largest population, has 35 seats; Togo, Liberia, Cape Verde, Guinea Conakry, Guinea Bissau, Republic of Benin, the Gambia, and Sierra Leone have 5 Parliamentarians each; Burkina Faso, Mali, Niger and Senegal have 6 Parliamentarians each; Cote d'Ivoire is entitled to 7 representatives; Ghana has 8.

\section{ENSURING PEACEFUL AND STABLE WEST AFRICA}

The basis for Nigeria and Ghana's commitment and involvement in ECOWAS security formation through peacekeeping missions in member states is to ensure a peaceful and stabilize region derived from their foreign policy direction which over the years 
helped defined their role in regional affairs. Nigeria`s Afrocentric principles of its foreign policy which has evolved over the years to meet contemporary challenges confronting the region from the African Centre-piece perspective, which is cooperation with immediate neighbors, cooperation with other ECOWAS member states and Promotion of peace. This is why O. Adedeji stresses that, "the idea of an Africa as the center piece of Nigeria foreign policy is premised on the understanding that Nigeria's engagement in the international system will be looked at through the binoculars of Africa" [Adedeji 1975: 67]. While, Aja Wachuku, argues that: "Nigerian foreign policy has been characterized by a focus on Africa as a regional power and by attachment to several fundamental principles: African unity and independence; capability to exercise hegemonic influence in the region: peaceful settlement of disputes; non-alignment and non-interference in internal affairs of other nations; and regional economic cooperation and development" [Wachukwu 1961: 20].

Ghana on the other hand pays attention to treaty obligations and settlement of international disputes by peaceful means. Through ECOWAS for instance, Ghana has been able to engage in numerous peacekeeping missions, which earns it international respect as a partner for global stability and a moral leader in African affairs. Unlike bigger economy such as Nigeria, Ghana's involvement in international peacekeeping functions sometimes aim at raising funds for its military due to scarce resources. Aside the training assistance it gets from these organizations, law enforcement officers' lifestyles are enhanced and they attain a broader perspective on areas such as human rights, different peacekeeping methods, and the image of Ghana on the international front. Ghana devote much attention to this type of foreign policy and also consider it to be an internal issue, since regional conflicts could potentially move into its territory and affect internal security [Birikorang 2007].

The Constitution of Ghana is clear in its dealings with other nations. The Directive Principles of State Policy, state its commitment to the principles and objectives upon which ECOWAS policies are based. Policies such as participation in regional peacekeeping are considered important to national well-being and the security of the country. H. Howe, for instance, argued that, "States often lack adequate military and police forces to control many of these conflicts", and adds that, "Western nations, often hesitate to help police conflicts which do not threaten their own vital interests, and the West and the United Nations have argued that sub-regional organizations and individual states should assume increasing security responsibilities" [Howe 1996-1997]. Based on Nigeria and Ghana's foreign policies ideological stand, both countries are member of the African Union (AU), the Economic Community of West African States (ECOWAS), the Non-Aligned Movement, the Commonwealth of Nations, and the United Nations.

Nigeria and Ghana's activities in ECOWAS peacekeeping operations started in the 1990s when then President Ibrahim Babagida of Nigeria and his counterpart President Jerry Rawlings of Ghana pushed for the formation of Economic Community of West African States Monitoring Group (ECOMOG) in 1990 as a result of the prevailing security situation in the region which originated from the Liberia civil war. Although, many still argue that, it lacked the legal framework of establishment. Nigerian scholar Adekeye Adebajo wrote in 2002 that "there was merit in the argument that the establishment of 
ECOMOG did not conform to the constitutional legal requirements of ECOWAS". Adebajo also contends that the arguments used to establish ECOMOG had more solid grounds in politics than in law. The Defense Protocol guidelines were not followed and ECOMOG was justified largely on humanitarian grounds.

While others argue that peace and security challenges in West Africa are primarily about responding to the various violent conflicts or the threat of violent conflicts, as well as building a sustainable peace with human security for all. Even, in the second half of the 20th Century, the African Continent has suffered enormously from violent conflicts within and between states than any part of the world [African Development Report 2008/2009...]. Again, Nigeria and Ghana recognized the fact that their respective internal security network is tied to regional security, this prompts the view that an injury to one is an injury to all. They also acknowledged the concept of peacekeeping which entails certain principles in undertaking any peacekeeping operation in ECOWAS member states. According to James, "the consent of the parties to the conflict; the use of force only in self-defense and more importantly, claims to impartiality. It is well documented that these principles which constitute the basic elements of classical peacekeeping have become problematic in many intra-state conflict situations" [James 1990].

\section{ECOMOG PEACEKEEPING OPERATIONS}

The ECOWAS nations assigned a non-aggression protocol in 1990 along with the earlier Protocol agreement on Mutual Defense Assistance signed in Freetown, Sierra Leone in May 1981, which provided for the establishment of an Allied Armed Force of the Community, ECOMOG ${ }^{2}$. ECOMOG, is the military arm of ECOWAS empowered to carry out Peacekeeping Operations among member states when call upon, the Peace Monitoring Group is backed by Article 58 of the Economic Community of West African States (ECOWAS) Charter. However, Article 58 of the revised treaty, which provides for regional security, contains the undertaking of member states to work to safeguard and consolidate relations, conducive to the maintenance of peace, stability and security within the region. The methodology of ECOMOG peacekeeping operations is within ECOWAS treaty in which member states reaffirm their commitment to the principles contained in the Charters of the United Nations Organization (UNO) and the Organization of African Unity (OAU) and to the Universal Declaration of Human Rights, as well as to the African Charter on Human and People's Rights ${ }^{3}$. This methodology could be classified into three, namely, intervention, peacekeeping and peace enforcement. These methods have been applied at various stages of conflicts in West Africa.

Many commentators argue that, the year 1990 - 2000 constituted a moment of truth for the hitherto little known sub regional organization, the Economic Community of West African States (ECOWAS). From being an economic community at its inception

${ }^{2}$ ECOWAS Convention on Small Arms and Light Weapons, their Ammunition and other Related Materials. ECOWAS Executive Secretariat. Abuja, 14 June, 2006, P. 5.

3 Protocol relating to the Mechanism for Conflict Prevention, Management, Resolution, Peacekeeping and Security. ECOWAS, 2007, P. 2. 
in 1975, ECOWAS literally reinvented its will in August 1990 to become, not only a collective security organization, but also a pacesetter in the development of regional collective security systems ingrained in the Chapter VIII of the United Nations Charter. In 1993, ECOWAS became the first regional alliance to undertake a joint 'peacekeeping' operation with the UN in the entire history of collective security. It matched this record in 1997 when it forcefully restored a democratically elected government in Sierra Leone, becoming the first regional organization to reinstate an overthrown government in Africa. James A. points that, "a peacekeeping body is a traditional-looking military force, composed of a number of battalions and the authority of a commander. The battalions will have been detached from or supplied by various national armies and the commander is appointed by, and it's responsible to the international authority which has arranged the operation" [James 1990].

It could be said that the alliance closed a decade of momentous events in its evolutionary history in December 1999 when it adopted a new protocol, which not only codified the controversial rights of humanitarian intervention and the use of force to restore democratic governments, but also empowered it to undertake enforcement action without the authorization of the Security Council. Former President Abubakar Abdulsalami of Nigeria argued that, "in the face of total neglect and ambivalence on the part of the international community, and faced with devastating humanitarian catastrophe, ECOWAS was compelled to intervene in Liberia" [Abubakar 2001:19]. Obviously, Nigeria is the backbone of ECOWAS security formation but not without the moral and logistical support of Ghana in reference to ECOMOG peace keeping and peace enforcement operations in Liberia (1990 - 1997), Sierra Leone (1996 - 1999), and Guinea Bissau (19981999) and the tremendous contribution of Nigeria and Ghana toward these peacekeeping operations is well documented. Obviously, Nigeria and Ghana's commitment and support base in promoting ECOWAS policies toward maintenance of peace in the region cannot be faulted.

Nigeria bears the larger cost of implementation of peacekeeping operations in West Africa and others peace related assignments. Aside, its armed forces, the largest and most equipped in the region, created a contingent of rapid deployment forces intended for operations in conflict zones. This was even adjudged by the United Nations in terms of military capability, which ranks the country as the fifth largest contributor to UN peacekeeping missions ${ }^{4}$. Stephen Ryan noted that, "When ethnic groups are engaged in violent conflicts, peacekeeping are often the most urgent and necessary of all peace strategies since it is the only one which deals directly with the warriors on all sides who are engaged in mutual destruction. Until this violent behavior is stopped, any attempt at resolution will be an exercise in futility. Peacekeeping is therefore seen as a temporary relief, in fact, a palliative, and not a cure" [Ryan 1995: 106] While Kehinde argues, "the role of regional organizations and their influence contributed to the decline of the Cold War, and ECOWAS duly took advantage of these changes in international politics" [Kehinde 2011].

${ }^{4}$ Economic Commission for Africa. UN. Fragile States and Development in West Africa, February, 2012. 
The highpoint of Nigeria and Ghana's activities in ECOWAS peacekeeping operations was when it's spearheaded ECOMOG peacekeeping operations under the mandate of ECOMOG Cease-Fire Peace Monitoring Forces to intervene in Liberia (19901998). Although, many see Ghana`s participation in the operation was initially been motivated by national interest, it later led to stabilizing peace and security in Liberia. However, some accounts suggest that, Ghana initially encouraged the idea of intervention, with a plan to rescue Ghanaians trapped at the embassy in Monrovia. It is therefore true to state that, Jerry Rawlings ' decision to intervene in Liberia was mainly to rescue Ghanaians whose lives were under serious threat, than on peacemaking concerns. Rawlings also thought the importance to include the regional leader (Nigeria) to generate international approval.

Nigeria contributed the bulk of troop and finance to the operation in Liberia while Ghana contributed little in term of military personnel and finance but played a vital role by opening its border for fleeing refugees and establishing humanitarian settlement in its territory. ECOMOG's operation in Liberia succeeded in containing the conflict, at lease for a short period, preventing the situation from degenerating into genocidal proportions like the type of all-out slaughter witnessed between April and July 1994 in Rwanda. The presence of a force of any nature in Rwanda would have at least prevented the allout slaughter, even if in the long run it did not succeed in resolving the conflict. While in Liberia, ECOMOG were involved in various types of missions; peace-keeping, peace enforcement, mediation, disarming of rebel groups, and the protection of humanitarian aids. ECOMOG peacekeeping operation ended in February 1998 but contingents of 5000 troops comprises of mostly Nigerians remained behind in capacity building roles. The conflict in Sierra Leone saw ECOMOG troops with contingents from Ghana, Guinea, Mali and Nigeria restored constitutional legality and reinstated the government of the democratically elected president" 5 . The operations at its peak had 13000 troops in the country which conducted both peacekeeping and peace enforcement operations. All the warring factions and the government later signed a peace agreement in Lome in September 1999 ending the Sierra Leonean crises. In 2000, the United Nations Peace keeping force UNAMSIL replaced ECOMOG.

Nigeria and Ghana strategic partnership in ECOWAS and ECOMOG in Liberia, Sierra Leone and other crises in the region is not without political bickering between the French and English speaking countries in the region, each bloc trying to protect their interests, due to the weak ECOWAS then existing protocols which were not totally favorable to intervene in security affairs of member states. Besides, Nigeria takes the larger burden of financing, training and equipping the ECOWAS military missions. Though, the intervention in the reference cases helped to stem the escalation of the conflicts but didn't totally solve the long run implications of post conflicts scenario. In view of the above peacekeeping operations none of the three interventions can be seen as a pure success but can be given a pass mark for allowing sequences peace negotiations to strive.

${ }^{5}$ Lessons Learned From United Nations Peacekeeping Experiences In Sierra Leone. Peacekeeping Best Practices Unit Department Of Peacekeeping Operations. UN. September, 2003, P. 7. 


\section{PERSPECTIVES OF ECONOMIC INTEGRATION}

Nigeria-Ghana carries out their actions within the legal framework of the ECOWAS Revised Treaty. For instance, Article 59: which state "Citizens of the community shall have the right of entry, residence and establishment and member states undertake to recognize these rights of Community citizens in their territories in accordance with the provisions of the Protocols relating thereto", and the United Nations General Assembly Resolution No. 60/277 on International Migration ${ }^{7}$. These countries position and common understanding is that, free movement within the region has contributed to the reduction in the migratory pressures even beyond ECOWAS borders and that, mobility within the ECOWAS zone is also a vital component of regional integration, which is itself a prerequisite for the West African economy's successful integration into the globalization process. "It should be taken under consideration that countries are always located in a particular geographical region, and they are forced to have relations with their neighbors which varies" [Pejic 2016: 494]. While such initiatives aim at the welfare of citizens of the ECOWAS, people in smaller countries such as Ghana consider this to be a threat to its local businesses.

The same constitution of Ghana which adheres to ECOWAS protocols has another act [Ghana Investment Promotion Centre (GIPC) act 2013 (Act 865)] that protects local businesses $^{8}$. The act, among other things, bars foreigners from engaging in petty trading and retailing, especially in areas designated as markets. Since the adoption of this act, government of Ghana has closed down several foreign businesses in the country. A development that triggered Nigerian Traders to drag Ghana to the ECOWAS Court in 2016, since the protocol on free movement of goods and people allows them to trade in any member country without hindrance. This questions Ghana's commitment to ECOWAS treaties when national interests are as stake. It again raises concern on whether the protocols itself have equally sensitized and mobilized support for the ECOWAS citizens, or they are only marginalized to the advantages of bigger countries such as Nigeria. Others also believed that, the perceived "advantages" informs Nigeria's commitment to the ECOWAS. The notion that, member states commitments are largely influenced by national interest is not farfetched preposition. Although part of Ghana's constitution pays attention to treaty obligations and "adhere to the principles enshrined in the ECOWAS Treaty". The above mentioned notwithstanding, reveals how a smaller country such as Ghana has used the organization to serve its national interest.

The core objective of ECOWAS is to integrate West African countries into an economic bloc with a single market organized around an economic and monetary union but this objective is far from reality. This concern was borne out of the realization that

${ }^{6}$ Ecowas Common Approach On Migration. 33rd Ordinary Session of the Head of State and Government Ouagadougou, 18 January 2008. URL: http://www.unhcr.org/49e47c8f11.pdf (accessed: 13.05.2016).

7 The United Nations General Assembly Resolution No. 60/277 on International Migration and Development of 7 April 2006.

8 The Ghana Investment Promotion Centre (GIPC) is a Government Agency established under the GIPC Act 2013 (Act 865) to create an enhanced, transparent and responsive environment for investment by promoting, coordinating and facilitating investment in the Ghanaian economy. 
the domestic markets of the member States taken individually as a result of their smallness, far from being competitive in a world environment marked by the existence of larger trade blocs. In the height of global economic meltdown of early 2000's experts still believe West Africa via Africa needs economic integration as way out of economic crisis. The views by experts on West Africa economic the smaller countries in ECOWAS disagreed with, ECOWAS economic intention is beyond individual member's market rather global competition. Although the economic potential of ECOWAS member states is positive, Nigeria, one of the ECOWAS member states has the biggest economy in Africa with her population of over $180 \mathrm{mln}$ people couple with abundance natural resources can provide a market base for other countries in the region.

As a regional leader, Nigeria is conscious of its own market potential to expand independently, rather persuade ECOWAS to implement actions such as: the suppression of custom duties and equivalent taxes; the establishment of a common external tariff; the harmonization of economic and financial policies; and the creation of a monetary zone, with the notion that it will promote economic progression in the region and beyond. This approach of Nigeria, Agyei et al, believed necessitated the need for economic integration which includes free flow of persons, goods and services, and the right of residence and establishment of businesses" [Agyei, Clottey 2007]. This gesture from Nigeria is with a strong resistance from ECOWAS member states; therefore the conclusion of some economists is that trade blocs have proved easier to form than common markets or full economic unions among sovereign nations because it is less bureaucratic and cumbersome. The same reasons responsible for the delay in ECOWAS full pledge on economic union. According to Kuffour, "inadequacy of the legal framework, failure to meet objectives of the community such as the Trade Liberalization Scheme (TLS), non-ratification of community protocols and a general sense of distrust towards the intentions of the regional hegemon, Nigeria" [Kuffour 2006: 127].

Considering the noble objectives of ECOWAS, economic union requires some degree of harmonization of national economic policies since it would be counterproductive to operate divergent policies, because all countries would share the same economic space. Total economic integration presupposes the unification of monetary, fiscal, social and countercyclical policies and requires the setting up of a supranational authority, the decisions of which are binding on member countries. The various economic policies initiated by ECOWAS require strong political will power to function, and the support of member countries in the region to comply rather than coercion. One of the major contributions of Nigeria and Ghana toward economic reform in the West African region was the introduction of ECOWAS Trade Liberalization Scheme in 1990. The protocol agreement signed by Nigeria and Ghana with five other ECOWAS states (Benin, Cote d'Ivoire, Mali, Burkina Faso and Niger) with the aim to establish a Free Trade Zone, the policy scheme is important to regional integration.

\section{ECOWAS POLITICAL REFORM}

The campaign and quest for political reform among ECOWAS member states through its protocol framework on sustainable democracy and good governance in the West African region is considered a priority agenda of ECOWAS, in order to safeguard the political stability in the region which is a precursor to peace and security, and also 
to give the region a positive image in the eyes of the international community. The adoption of ECOWAS revised treaty has put forward a lot of reforms currently sweeping the region in favor of political pluralism which will help to narrow political and ideological differences among member states. This tendency was reinforced by the Community's adoption in 1991 of the Abuja Declaration of Political Principles, which enshrines a minimum set of democratic principles as guidance to member states in their quest for a well-established democratic society. This is a modest beginning of political cooperation, but constitutes a vital step nonetheless. The revised Treaty also envisages the establishment of a West African parliament to promote grassroots involvement and popular participation in regional integration and cooperation.

This is also the core objective of Nigeria's foreign policy approach in the West African region because of the widely held opinion by international political commentators on African affairs that, political instability is one of the bane hindering the growth and developmental process in the continent, which has also slowed down the regional integration process. The frequent change of government through unconstitutional means attested to this widely held view by international community. According to Nwauwa, "it became the most prevalent political phenomenal between 1960 and 1970 and slightly beyond which was generally called the "decade of coups" in Africa" [Nwauwa 2009].

The political impasse in the region circles around the Francophone states in particular, and other states in the sub-region in general viewed Nigeria with suspicion. The sharp ideological differences between the Anglophone countries and their Francophone counterparts created a rift in the regional integration process with no recognized official leader in the region. The development prompts Danjuma, to states that "the unacceptable of Nigeria leadership role in the region provides them alternative form of security arrangement for their self-pride and protection". The adventurism of military into politics in West Africa citing several reasons, such as; political squabbling, whereby the civilian leaders have been unable to resolve their differences in the interest of the nation, has led to series of military coups, internal political problems within the ruling elite have had the outward effect of leading the masses into disappointment, disillusion and loss of faith in the government. Nigeria is a frontline state in the promotion of democracy and good governance within ECOWAS.

The relatively political stability experienced among ECOWAS member states is largely traced to Nigeria's leadership capability and Ghana consistence in its political system which is serving as a reference case to other ECOWAS member states. The various ECOWAS Protocol mechanisms in resolving political crisis in the region has proved effective although not totally agreed to by opposing views. Nigeria and Ghana identify the fact that, there is no meaningful economic growth in atmosphere of political instability, and they also agreed that the key to realistic sub-regional peace and political stability was the establishment of strong democratic institutions in the region according to the constitution, and the will of the people of ECOWAS member states to sustain enduring democratic culture in the West African region. Based on the above factor,

9 Danjuma, T.Y. (2012). Nigeria's Security Role in West Africa. http://www.onlinenigeri.com/ finance/?blurb=44accessedon06/01/2012 (accessed: 13.06.2016). 
Danjuma, Y. argues that, "when Nigeria carries out political and military gestures to individual states or groups of states in West Africa, it is also addressing the problems of the sub-region" 10 .

The solidarity ECOWAS is receiving from Nigeria and Ghana is to ensure total compliance by member states with ECOWAS political reform which aims at restructuring the old existing political structure that has caused the region political instability for decades and reposition it into modern political space. For instance, the recent elections conducted in various countries in ECOWAS attest to the political reformation going on in the West African region which have gradually helped to remove the primary obstacles to integration. The abolition of military rule and unconstitutional change of government, and insistence on multi-party and enduring democracy in most ECOWAS countries, particularly Nigeria which is the dominant country in West Africa. This has helped to stabilize the political arena which is prelude to total integration. The anticipation of political instability in the region resulting from internal rivalry among stakeholders prompted the enforcement of ECOWAS 2001 Protocol on good governance and unconstitutional change of government initiated by Nigeria which has the full backing of Ghana.

The protocol agreement makes provision for sanctions to be imposed where domestic or regional norms of constitutional provisions are breached, at least in cases of unconstitutional change of government. The key protocol provisions are contained in Articles 2 and 45. According to Article 2 (1), "no substantial modification shall be made to the electoral laws in the last six (6) months before the elections, except with the consent of a majority of political actors" ${ }^{11}$ (ECOWAS, 2001). Where it appears that this norm may be breached, ECOWAS could resort to the good offices of the Mediation and Security Council and the Panel of the Wise (Council of the Elders) to engage political actors and remind them of their legal commitment to regional norms. The ultimate aim is to return democracy to the country in question, upon recommendation of the Mediation and Security Council; sanctions may be imposed by the Authority of Heads of State and Government.

The uninterrupted democratic system in Nigeria since 1999 and that of Ghana since 1992 reawakened the call for sustainable political reformation and stability agreed on by ECOWAS leaders. In reaffirmation of its commitment to this course, Nigeria and Ghana together with other ECOWAS Heads of State and Government came up with a resolution "ECOWAS Vision 2020". It envisions that by 2020, ECOWAS will be "A boarder less, peaceful, prosperous and cohesive ECOWAS sub-region built on good governance where all the people have the capacity to access and harness the region's abundant resources through the creation of equal opportunities for sustainable development and environmental preservation"12.

10 Danjuma, T.Y. (2012). Nigeria's Security Role in West Africa. http://www.onlinenigeri.com/ finance/?blurb=44accessedon06/01/2012 (accessed: 13.06.2016).

112001 protocol on governance and unconstitutional change of government. ECOWAS. Abuja, Nigeria.

${ }_{12}$ Hart, K. (2013). West African political economy: a regional history. The Memory Bank URL: http://thememorybank.co.uk/2013/07/31/west-african-political-economy-a-regional-history (accessed: 13.06.2016). 
The activities of Nigeria and Ghana in West African regional political integration process through the mechanism of ECOWAS has brought positive changes to the region quest to ensure the establishment of democratic culture in ECOWAS member states. Their exemplary political transformation in their respective countries through ECOWAS protocol has intervened in countries where there were military coup d'états and political crises to restore legitimate governments. Starting with Liberia in 2003, as part of the solution to find amicable settlement to the repeated Liberia political crisis after prolong political dispute, the Nigerian government offered President Charles Taylors's asylum before the arrival of the UN troops in Monrovia in August 2003 which paved way for presidential election. Before this offer, Nigeria, Ghana and Guinea had already deployed their troops in the country, in the buildup to the formation of the Interim Government in Liberia, between September 2003 and January 2004.

Again, the mission of Nigeria in Sierra Leone through ECOWAS legal framework was defined, to restore democracy to the country after the unconstitutional change of government by the military in 1998. Nigerian troops through the mandate of ECOWAS were instrumental in the reinstatement of the democratically elected government of Ahmed Tejjan Kabbah in Sierra Leone after the military coup d'état led by Major John Koroma in 1998. Many political analysts see the development as an offshoot of Liberia crisis. George contends that, "the Sierra Leone Conflict was an overflow of the Liberian Civil War". President Ahmed Tejjan Kabbah, invited ECOWAS to help restore him to power after the military overthrew his government. The urgent request was taken by Nigeria, bearing in mind the country just came out of civil war and the region could not afford to witness another outbreak of civil war because of its devastating effects.

After this noble act, Nigeria proposed the motion on the ECOWAS Protocol on 'Unconstitutional Change of Government' which was adopted in 2000 and eventually led to the resolution by ECOWAS to reject any unconstitutional change of government, which became a key part of the Protocol on Good Governance and more elaborately developed in the ECPF of 2008. Nigeria in 2001, showed its commitment to the peace accord signed in Lome, by donating one million dollars and a contingent of police officers to help restore order in Sierra Leone, while additional five hundred thousand dollars was donated in support of the January/May 2002 general elections. The role played by Nigeria helped to stabilize the volatile political situation in Sierra Leone which by extension West African region. The resources Nigeria channeled into West Africa project cannot be quantified, this made Bamali N. to state that, "Nigeria has borne the greatest burden in terms of peacekeeping in West Africa. By 1999, it was estimated that Nigeria had committed 13 billion US dollars to peacekeeping operations in West Africa" [Bamali 2007].

Other subsequent political interventions by ECOWAS in which Nigeria and Ghana played prominent role are: Cote d'Ivoire: fallout from presidential election (2010), Mali: Military coup (2012), Guinea: Military coup (2007), Guinea Bissau: Military coup (1998), Niger: Constitutional crisis (2009), Togo: Constitutional crisis (2004), Burkina Faso: Constitutional crisis (2014). The climax of Nigeria and Ghana's role in ECOWAS political intervention is the amicable settlement of the recent Gambia's political crisis without military confrontation. The crisis started in December 2016 as a result of dis- 
puted presidential election result which was not accepted by the incumbent president Yaya Jammah though he initially consent defeat to his rival Adama Barrow but later made a volte face thereby attracting the intervention of ECOWAS through its protocol on sustainable democracy and good government. ECOWAS Summit held on December 17, 2016 in Abuja took the decision to designate President Muhammadu Buhari as the Mediator for The Gambia with John Mahama, the former President of Ghana as CoMediator. The Summit also gave the terms of reference to include, "ensuring the safety of the President-Elect, Adama Barrow, the political leaders and the entire population; upholding the result of the Presidential election held on December 1, 2016 and ensuring that the President-elect is sworn into office on January 19, 2017, in conformity with the constitution of the country"13. The prompt action of ECOWAS mediate committee led to the swearing of the winner of the disputed presidential election Adama Barrow after so much resistant from the incumbent president.

The main reason ECOWAS is strict in enforcing its protocol of sustainable democracy and good governance among member states, is to ends tyranny, dictatorship, autocratic and military regimes which had hindered the progress of the region. Hence, ECOWAS insists the will and the constitution of member states must be allowed to prevail by political stakeholders, therefore good governance is necessary not the yardstick for ECOWAS intervention in the political crisis of member states, but rather to ensure the preservation of the will of the people and the constitution of member states. Based on this fact, the intervention of ECOWAS in the Gambia and other ECOWAS member states is justified because there is no parameter to measure good governance in ECOWAS treaty and there is no standard gauge to evaluate democracy except the constitutional provisions of each member states.

One identical feature which plays an important role in both Nigeria and Ghana's foreign policy is maintaining good relations and co-operations with any country that may be interested in that co-operations and ideologies within the West Africa context and beyond. Nigeria uses its capability to exercise hegemonic influence in the region, through peaceful settlement of disputes by contributing larger resource within the ECOWAS bloc. These kinds of involvements provide an opportunity for a country like Ghana to use its scarce resources for other internal development. While Nigeria sees it as an opportunity to test its military might which helps to maintain its hegemonic influence in the region. Ghana on the other hand, uses international organizations such as ECOWAS to get its voice heard on the international stage. In spite of the ideological position and leadership style, the two countries devote much attention to this type of foreign policy and also consider it to be an internal issue, since regional conflicts could potentially move into its territory and affect internal security. One is therefore challenged to see how democratic credentials of the two countries, efforts and concrete events cohere and advance the author's argument as well as lend assertions and evidence to the fact that, Ghana and Nigeria indeed, is indeed a committed member and key factor in the ECOWAS integration process.

${ }^{13}$ ECOWAS Mandate, December 31, 2016, Press Release. Nigeria. 


\section{REFERENCES}

Abubakar, Abdulsalami A. (2001). Regional Integration and Conflict Management: ECOWAS and the Challenges of the Twenty-first Century. Annual Distinguished Lecture. Institute of Governance and Social Research.

Adedeji, O. (1975). Nigeria Foreign Policy Formation Stage. Ibadan: University Press.

Adekeye, Adebajo. (2002). Liberia's Civil War: Nigeria, ECOMOG and Regional Security in West Africa. Lynne Rienner / International Peace Academy.

Agyei, J., \& Clottey, E. (2007). Operationalizing ECOWAS Protocol on Free Movement of People among the Member States: Issues of Convergence, Divergence and Prospects for Sub-Regional Integration. URL: https://www.imi.ox.ac.uk/events/ghana-african-migrations-workshop/papers/ clottey.pdf (accessed: 13.05.2016).

African Development Report 2008 / 2009. African Development Bank. Oxford: Oxford University Press. URL: https://www.afdb.org/fileadmin/uploads/afdb/Documents/Publications/African\%20 Development\%20Report\%202008-2009.pdf (accesses: 13.05.2016).

Bamali, Nuhu. (2007). Redefining Nigeria's interest and Commitments in Peace Support Operations. In: Akinterinwa Bola, editor, Nigeria's National Interests in a Globalising World: Further Reflections on Constructive and Beneficial Concentricism (Volume Three: Nigeria's National Interests Beyong Nigeria). Ibadan: Bolytag International Publishers. p. 68-109.

Birikorang, E. (2007). Ghana's Regional Security Policy: Cost, benefits and consistency. Kofi Annan International Peacekeeping and Training Centre (KAIPTC). Accra, Paper N 20. 2.

Cochrane, J. (1969). The Politics of Regional Integration: The Central American Case. Tulane University: Tulane Studies in Political Science.

Herrera, F. (1963). Economic Integration and Political Re-integration. In: Latin America: Evolution or Explosion. New York: Doad Meed and Co. P. 94-95.

Howe, H. (1996 - 1997). Lessons of Liberia and Regional Peacekeeping. International Security, 21 (3), $145-179$.

James, A. (1990). Peace Keeping in International Politics. London: Macmillan.

Kehinde, A. Bolaji. (2011). Adapting traditional principles: The ECOWAS Conflict Prevention Framework. African Conflict \& Peacebuilding Review, 1 (2), 183-204.

Kuffour, K. O. (2006). The Institutional Transformation of the Economic Community of West African States. Accra: Ashgate Publishing.

Nwauwa, A. (2009). Concepts of Democracy and Democratization in Africa Revisited. In: Charles Nieman, editor, Democracy and Globalization. Kent State University Press.

Nwoke, C. N. (2005). Nigeria and ECOWAS. In: Ogwu U. J., editor. New Horizons for Nigeria in World Affairs. Lagos: NIIA. p. 111-156.

Pejic, I. (2016). Western Balkans in the light of regional security complex theory. Vestnik RUDN. International relations, 16 (3), 494-504.

Radelet, S. (2010). Success stories from "Emerging Africa”. Journal of Democracy, 21 (4), 87-101. Ryan, S. (1995). Ethnic Conflict and International Relations. Hants: Dartmouth.

Wachukwu, A. (1961). Establishing Nigeria' Foreign Policy Identity. Federal Ministry of Foreign Affair. Lagos.

For citations: Omo-Ogbebor, Dennis O., Sanusi, Ahmed H. (2017). Asymmetry of ECOWAS integration process: contribution of regional hegemon and small country. Vestnik RUDN. International Relations, 17 (1), 59-73.

\footnotetext{
About the authors:

Omo-Ogbebor Dennis $O$. - postgraduate student of the Department of the Theory and History of International Relations of the Peoples' Friendship University of Russia (RUDN University) (e-mail: samsuyi2002@yahoo.co.uk).
} 
Sanusi Ahmed H. - postgraduate student of the Department of Theory and History of International Relations of the Peoples' Friendship University of Russia (RUDN University) (e-mail: hajjsanusi@yahoo.com).

\title{
АСИММЕТРИЯ ИНТЕГРАЦИИ В РАМКАХ ЭКОВАС: ВКЛАД РЕГИОНАЛЬНОГО ГЕГЕМОНА И МАЛОЙ СТРАНЫ
}

\author{
Деннис О. Омо-Огбебор, Ахмед Х. Сануси \\ Российский университет дружбы народов, Москва, Россия
}

\begin{abstract}
В статье анализируется роль Нигерии и Ганы в интеграционных процессах в рамках ЭКОВАС с момента создания организации в 1975 г. Данное исследование демонстрирует основные параметры участия Нигерии как регионального лидера и ключевую роль Ганы в процессе интеграции ЭКОВАС в контексте внешней политики этих стран в XXI в.

Для оценки роли Нигерии и Ганы в процессе региональной интеграции авторы должны были решить три основные задачи. Первая - определение ключевых направлений интеграционного процесса в рамках ЭКОВАС (экономическая интеграция, региональная безопасность и политические реформы) с помощью качественного методологического анализа. Вторая — анализ организационной структуры ЭКОВАС. Решение этой задачи позволяет выявить особый статус Нигерии в ЭКОВАС и степень влияния малой страны (на примере Ганы). И третья задача заключается в оценке деятельности Нигерии и Ганы в рамках ЭКОВАС в области экономической либерализации, операций по поддержанию мира, а также политических реформ в контексте внешней политики данных стран в регионе Западной Африки.

В заключение авторы приходят к выводу, что, несмотря на асимметрию структуры ЭКОВАС, которая также включает в себя и франкоязычные страны региона, Нигерия и Гана вносят важный вклад в деятельность организации, поскольку уделяют особое внимание интеграционным инициативам ЭКОВАС посредством медиации, поддержания мира, политических реформ и экономического сотрудничества.
\end{abstract}

Ключевые слова: Нигерия, Гана, интеграции, ЭКОВАС, ЭКОМОГ, Африка, внешняя политика, экономическое сотрудничество, поддержание мира, политические реформы

Дата поступления статьи: 13.02.2016

Для цитирования: Omo-Ogbebor Dennis O., Sanusi Ahmed H. Asymmetry of ECOWAS integration process: contribution of regional hegemon and small country // Вестник Российского университета дружбы народов. Серия: Международные отношения. 2017. Т. 17. № 1. С. 59-73.

\section{Сведения об авторах:}

Омо-Огбебор Деннис О. - аспирант кафедры теории и истории международных отношений факультета гуманитарных и социальных наук Российского университета дружбы народов (e-mail: samsuyi2002@yahoo.co.uk).

Сануси Ахмед $X$. - аспирант кафедры теории и истории международных отношений факультета гуманитарных и социальных наук Российского университета дружбы народов (e-mail: hajjsanusi@yahoo.com) 